\title{
PENGEMBANGAN SCIENCE DAN TECHNOPARK DALAM MENGHADAPI ERA INDUSTRI 4.0 - SEBUAH STUDI PUSTAKA
}

\author{
Leo Aldianto, Leo Aldianto, Isti Raafaldini Mirzanti, Dedy Sushandoyo, Emilia \\ Fitriana Dewi \\ Institut Teknologi Bandung
}

JURNAL

MANAJEMEN

INDONESIA

\begin{abstract}
Abstrak
Indonesia mulai menghadapi era Industri 4.0, dimana semua sistem mulai terhubung secara digital. Tentu saja perkembangan industri ini memiliki manfaat yang sangat besar karena dapat mengoptimalkan dan menyederhanakan rantai suplai bisnis. Tantangan terbesar menghadapi revolusi Industri 4.0 adalah dalam menciptakan teknologi dan pendekatan baru yang menggabungkan dunia fisik dan digital. Di era ini kolaborasi menjadi sangat penting, terutama dalam proses komersialisasi hasil penelitian yang tepat guna yang dilakukan oleh akademisi yang dapat diaplikasikan dan dipasarkan oleh pebisnis atau industri. Peran serta pemerintah menjadi sangat krusial untuk membangun ekosistem yang mendukung dan berkelanjutan. Salah satu strategi yang dikembangkan di Indonesia adalah dengan menciptakan Science dan Technopark, yaitu sebagai hub yang dapat meningkatkan jejaring dan kolaborasi antar pemangku kepentingan. Penelitian ini fokus pada studi pustaka, dengan melakukan tinjauan terhadap penelitian terbaru yang berhubungan dengan Industri 4.0 dan juga berkaitan dengan Science dan Technopark. Hasil penelitian ini bermanfaat sebagai rekomendasi dalam mengembangkan Science dan Technopark di Indonesia.
\end{abstract}

Kata kunci : Industri 4.0, Inkubator Bisnis, Komersialisasi Teknologi, STP

\begin{abstract}
Indonesia faces the era of Industry 4.0, in which all systems are connected. This development has a huge advantage among others in both simplifying and optimizing the supply chain. The main challenges in Industry 4.0 revolution include the relevant technology creation and some new approaches in combining physical and digital world. Therefore good collaboration between researchers and business or industry for commercializing research results becomes critical. Government may play an important role to build the necessary ecosystem for sustained innovation. Indonesia has started the initiatives to develop Science and Techno Park as a hub to increase the network and collaboration between all stakeholders. This study focuses on that Science and Techno Park development in the context of Industry 4.0 development. The study proposes some recommendation for developing Indonesia's Science and Techno Park.
\end{abstract}

Keywords : Commercializing, Ecosystem, Industry 4.0, Science and Techno Park

\section{Pendahuluan}

Saat ini, dalam industri manufaktur mulai dikenalkan dengan konsep Industri 4.0. Berdasarkan GE Report (2016), industri 4.0 adalah manufaktur yang terhubung secara digital, mencakup berbagai jenis teknologi, mulai dari 3D printing hingga robotik, jenis material baru serta sistem produksi. Perkembangan industri ini memiliki manfaat yang sangat besar karena dapat mengoptimalkan serta menyederhanakan rantai suplai manufaktur, dengan cara mengintegrasikan secara digital sistem manufaktur.

Saat ini perkembangan industri 4.0 juga didukung oleh kemajuan teknologi yang sangat pesat. Perkembangan teknologi ini memungkinkan terjadinya otomatisasi hampir di semua bidang. Perkembangan internet of thing (IoT) yang tanpa batas dapat merubah seluruh proses manufaktur dan bisnis. IoT adalah sebuah konsep dimana suatu objek yang memiliki kemampuan untuk mentransfer data melalui jaringan tanpa memerlukan interaksi manusia ke manusia atau manusia ke komputer. IoT telah berkembang dari konvergensi teknologi

Vol.18 No.1

April 2018 
nirkabel, micro-electromechanical systems, dan Internet. IoT pada prinsipnya seperti juga tujuan dari teknologi itu sendiri adalah mempermudah aktifitas manusia.

Perubahan kondisi tersebut di atas tentunya dapat membuka peluang bisnis dan pasar baru untuk para penyedia dan pengembang teknologi, seperti sensor, robotik, 3D printing atau teknologi komunikasi antar mesin. Pada penelitian ini akan membahas mengenai pengembangan peran suatu entitas yaitu science dan technopark (STP) yang dapat mendukung dalam menghadapi era industri 4.0 .

\section{Studi Pustaka}

Konsep Industri 4.0 pertama kali diperkenalkan pada tahun 2010, pada saat Kementerian Pendidikan dan Penelitian Federal Jerman (German Federal Ministry of Education and Research) mendesak untuk mengidentifikasi tren teknologi tinggi dan dampaknya terhadap masyarakat. Pada saat inilah Industri 4.0 dimulai dan tren baru terjadi diberbagai industri (Kemper, 2016).

Menurut Kemper (2016) Perusahaan yang siap menyambut revolusi industri 4.0 adalah perusahaan yang dapat membangun ekosistem produksi berbasis konsep Industri 4.0, seperti perusahaan-perusahaan yang dapat menyediakan infrastruktur jaringan untuk Industrial Internet. Bagi negara-negara maju, Industri 4.0 dapat menjadi cara untuk mendapatkan kembali daya saing infrastruktur, khususnya bagi negara-negara Eropa Barat, yang saat ini tidak mengalami pemotongan biaya listrik seperti di AS. Sedangkan bagi negara-negara berkembang, Industri 4.0 dapat membantu menyederhanakan rantai suplai produksi. Hal ini tentu saja sangat dibutuhkan untuk menekan biaya produksi yang terus meningkat.

Tahun 2011 menandai penggunaan resmi pertama dari istilah Industri 4.0. Publisitas dan demonstrasi bagaimana hal itu bisa menguntungkan perusahaan mulai muncul dalam presentasi. Pada tahun 2013, industri manufaktur Jerman memilih untuk berinvestasi dalam proses Industri 4.0 dan pemerintah Jerman meningkatkan pendanaan, yang menyebabkan Platform Industri 4.0 dibuat. Pada tahun 2014, mulai terjadi aktifitas manufaktur digital produk dan pemanfaatan IoT (Kemper, 2016).

Perkembangan IoT sejalan dengan Industri 4.0, walaupun hingga saat ini memang belum ada definisi yang pasti dari IoT, penelitian pada bidang IoT masih dalam tahap perkembangan. Berikut adalah beberapa definisi alternatif dikemukakan untuk memahami IoT. Menurut Ashton (2009) definisi awal IoT adalah Internet of Things memiliki potensi untuk mengubah dunia seperti pernah dilakukan oleh Internet. Menurut IDCH (2016) "A Things" pada IoT dapat didefinisikan sebagai subyek misalkan orang dengan monitor implant jantung, hewan peternakan dengan transponder biochip, sebuah mobil yang telah dilengkapi built-in sensor untuk memperingatkan pengemudi ketika tekanan ban rendah. Sejauh ini, IoT paling erat hubungannya dengan komunikasi machine-to-machine di bidang manufaktur dan listrik, perminyakkan, dan gas. Produk dibangun dengan kemampuan komunikasi Machine to machine yang sering disebut dengan sistem cerdas atau "smart". Sebagai contoh yaitu smart cable, smart meter, smart grid sensor.

Menurut Atzori, et al. (2010), Casagras (Koordinator dan Tindakan Dukungan untuk Kegiatan RFID global/Coordinator and support action for global RFID-related activities and standadisation) mendefinisikan IoT sebagai sebuah infrastruktur jaringan global, yang menghubungkan benda-benda fisik dan virtual melalui eksploitasi data capture dan kemampuan komunikasi. Infrastruktur terdiri dari jaringan yang telah ada dan internet berikut pengembangan jaringannya. Semua ini akan menawarkan identifikasi obyek, sensor dan kemampuan koneksi sebagai dasar untuk pengembangan layanan dan aplikasi ko-operatif yang independen, ditandai dengan tingkat otonom data capture yang tinggi, event transfer, konektivitas jaringan dan interoperabilitas.

Tantangan terbesar yang sedang dihadapi dunia saat ini, adalah bagaimana membentuk revolusi Industri 4.0, dalam menciptakan teknologi dan pendekatan baru yang menggabungkan dunia fisik, digital, dengan cara yang fundamental yang dapat merubah perilaku manusia (Tjandrawinata, 2016). Perubahan industri dalam bentuk manufaktur aditif, material canggih, mesin cerdas, mesin otomatis, dan teknologi lainnya, mengantarkan era baru produksi fisik. Pada saat yang sama, peningkatan konektivitas dan kemampuan pengumpulan data dan analitik yang lebih canggih yang dimungkinkan oleh IoT telah mengarah pada

\section{Jurnal Manajemen Indonesia}


pergeseran menuju ekonomi berbasis informasi. Dengan IoT, data, selain objek fisik, merupakan sumber nilai dan konektivitas memungkinkan untuk membangun rantai pasokan yang lebih cerdas, proses manufaktur, dan bahkan ekosistem dari hulu ke hilir (Sniderman et al., 2016).

Berbagai negara berbeda-beda dalam menghadapi Industri 4.0, sebagai contoh, di Cina rencananya dalam 10 tahun ke depan menargetkan sektor-sektor inti seperti robotik, teknologi informasi dan energi, dalam upaya mengubah negara yang kini dikenal sebagai "raksasa manufaktur" menjadi "penggerak manufaktur dunia". Strategi Cina untuk mencapai tujuan tersebut adalah dengan cara meningkatkan nilai investasi R\&D hingga 1,7\% dari jumlah total pendapatan manufaktur di tahun 2025 (Kemper, 2016).

Di Indonesia, salah satu strategi yang dilakukan oleh pemerintah adalah dengan meningkatkan komersialisasi teknologi yang tepat guna dengan cara kolaborasi antara industri, pemerintah, dan akademisi mulai gencar dilakukan, termasuk juga dengan meningkatkan dana investasi untuk melakukan riset di institusi pendidikan. Menurut Kementerian Riset Teknologi dan Pendidikan Tinggi dana riset yang dialokasikan pada 2018 meningkat menjadi $\mathrm{Rp} 2,45$ triliun, dimana tahun sebelumnya adalah $\mathrm{Rp} 2,1$ triliun. Dana riset sebesar tersebut akan difokuskan pada lima program khusus yaitu bidang energi, pangan, kesehatan, kemaritiman, dan pariwisata. Kelima bidang tersebut merupakan bagian dari sepuluh rencana induk riset Indonesia pada 2015-2045.

Hasil penelitian tersebut bukan hanya dimaksudkan untuk meningkatkan jumlah publikasi hasil penelitian tetapi dapat diimplementasikan untuk mendukung Industri 4.0, seperti yang dilakukan di negara-negara lain. Untuk mendukung strategi tersebut, pemerintah Indonesia melakukan program kolaborasi antar industri, akademisi, dan pemerintah. Pemerintah menetapkan prioritas program dan membentuk infrastuktur yang mendukung aktifitas tersebut, industri berperan serta dalam mendukung penggunaan hasil penelitian, sedangkan akademisi berperan dalam melakukan penelitian yang berkelanjutan yang dapat menghasilkan teknologi tepat guna yang memiliki daya saing untuk meningkatkan ekonomi negara. Aktivitas tersebut diatas dilakukan dalam sebuah ekosistem yang bernama Science dan Technopark.

Pemerintah telah mendorong berdirinya science dan technopark di berbagai kota. Sampai sekarang, Indonesia telah memiliki sejumlah science dan technopark yang menyebar di seluruh Indonesia. Mengingat konsep ini masih baru diimplementasikan di Indonesia, keberhasilannya masih membutuhkan proses yang relarif panjang. Evaluasi terhadap keberadaan technopark menjadi penting demi keberlanjutan dan peningkatan fungsi dari technopark-technopark yang telah ada sampai saat ini. Indonesia di bawah Bappenas telah mulai menginisiasi berkembangnya science dan technopark. Bappenas mulai mengembangkan Pedoman Perencanaan science dan technopark tahun 2015-2019 di bawah Deputi Bidang Ekonomi. Bagaimana cita-cita pendirian science dan technopark dimulai dari dokumen negara Nawa Cita.

Menurut International Society of Science Park, Science and Technopark sering diartikan sebagai formula/ konsep organisational yang mempunyai ciri-ciri sebagai berikut:

- Diciptakan dengan tujuan untuk menginisiasi bisnis yang didasarkan atas ilmu pengetahuan/ teknologi

- Memiliki keterkaitan secara operasional dengan universitas atau lembaga penelitian

- Memiliki struktur manajemen yang terlibat dalam transfer teknologi dan penciptaan kondisi bagi pengusaha (entrepeneur) dalam menjalankan dan mengefisienkan aktifitas bisnisnya

- Keberadaan perusahaan (besar atau startup) sebagai pelaku komersial untuk menjawab kebutuhan pelanggan

Mengacu pada The International Association of Science Parks (IASP):

"A science park or innovation park adalah organisasi yang dikelola oleh profesional khusus, yang tujuan utamanya adalah untuk meningkatkan kekayaan komunitasnya dengan mempromosikan budaya inovasi dan daya saing bisnis terkait dan institusi berbasis pengetahuan." 
Berdasarkan Felsenstein (1994), Science Park mempunyai dua fungsi. Pertama, sebagai persemaian dan daerah yang melindungi teknologi dan memainkan peran sebagai inkubator, melindungi dan mengembangkan perusahaan-perusahan mula, perusahaan berbasis teknologi dan memfasilitasi transfer teknologi antar pusat penelitian/universitas dengan perusahaanperusahaan yang berada di sana (tenant), mendorong munculnya spin-off dari penelitianpenelitan yang dilakukan oleh universitas dan menstimulasi munculnya produk dan proses yang inovatif. Kedua, tujuan atau fungsi yang kedua adalah sebagai katalis bagi pengembangan ekonomi disuatu daerah (regional economic development) dan revitalisasi ekonomi suatu daerah.

\section{Metoda Riset}

Studi pustaka tentang topik tertentu dapat memberikan pengalaman yang memperkaya secara akademis. Studi ini harus dianggap sebagai proses yang fundamental bagi setiap penelitian atau pengembangan yang bermanfaat dalam subjek apa pun terlepas dari disiplinnya. Metoda penelitian memiliki tanggung jawab untuk mencari tahu apa yang sudah ada di daerah mana penelitian tersebut diajukan. Studi literatur membentuk landasan untuk penelitian yang tepat (Hart, 1998).

Berikut ini adalah tujuan studi pustaka dalam penelitian:

- Membedakan apa yang telah dilakukan dari apa yang perlu dilakukan

- Menemukan variabel penting yang relevan dengan topik tersebut

- Mensintesis dan mendapatkan perspektif baru

- Mengidentifikasi hubungan antara ide dan praktik

- Menetapkan konteks topik atau masalah

- Rasionalisasi pentingnya masalah

- Meningkatkan dan memperoleh kosakata subyek

- Memahami struktur subyek

- Menghubungkan ide dan teori dengan aplikasi

- Mengidentifikasi metodologi utama dan teknik penelitian yang telah digunakan

- Menempatkan penelitian dalam konteks historis untuk menunjukkan keakraban dengan perkembangan state-of-the-art

Penelitian ini dilakukan dengan melakukan studi pustaka. Pustaka yang dicari mulai Januari 2015 hingga 2017, menggunakan kata kunci science and techno park, innovation park, Industri 4.0. Sumber pencarian termasuk jurnal, proceeding, dan buku. Wawancara dengan pelaku juga dilakukan untuk memvalidasi hasil. Menurut Hart (1998), studi pustaka adalah pemilihan dokumen yang tersedia (baik yang diterbitkan dan tidak dipublikasikan) pada topik, yang berisi informasi, ide, data dan bukti yang ditulis dari sudut pandang tertentu untuk memenuhi tujuan tertentu atau mengungkapkan pandangan tertentu pada topik tersebut, bagaimana menyelidikinya, dan evaluasi efektif dari dokumen-dokumen ini dalam kaitannya dengan penelitian yang dilakukan.

Metode sistematis untuk melakukan tinjauan pustaka diadopsi dari karya Levy dan Ellis (2006), yang dikenal sebagai pendekatan "input-processing-output". Pendekatan yang diusulkan terdiri dari tiga tahap utama sebagai berikut:

- Input adalah proses pengumpulan dan penyaringan literatur termasuk metode untuk mengidentifikasi sumber literatur, membaca literatur penelitian, dan mengetahui bagaimana penelitian sebelumnya dilakukan dengan pencarian literatur.

- Process adalah proses menganalisis, mensintesis, dan mengevaluasi literatur penelitian.

- Keluarannya adalah proses penulisan tinjauan pustaka, sintesa kajian pustaka dan mengikuti teori argumen.

Studi pustaka yang efektif membantu para peneliti untuk menjawab isu-isu berikut (Iivari et al., 2004):

\section{Jurnal Manajemen Indonesia}


- Untuk membantu memahami tubuh pengetahuan yang ada termasuk di mana untuk mengakses penelitian yang ada.

- Untuk memberikan latar belakang teoritis yang kuat untuk topik penelitian yang dipilih.

- Untuk mengungkap masalah penelitian.

- Untuk membenarkan kontribusi topik penelitian yang dipilih sebagai sesuatu yang baru bagi tubuh pengetahuan.

- Untuk membangun metodologi penelitian yang valid, pendekatan, tujuan, dan pertanyaan penelitian untuk topik penelitian yang dipilih.

JURNAL

MANAJEMEN

INDONESIA

Vol.18 No.1

April 2018

\section{Hasil dan Analisis}

Pentingnya pengembangan science dan technopark dalam menghadapi perubahan industri, dalam kondisi saat ini adalah revolusi era Industri 4.0, perlu melihat bagaimana pembentukan dan keberhasilan pengembangan science dan technopark di negara lain. Di US science dan technopark muncul sebagai bentuk pengembangan pusat inovasi dan implementasi. Mulai berkembang pada awal 1950-an, ketika sebuah research park didirikan di Stanford University, California. Tanah dan ruangan disewakan kepada usaha kecil dan perusahaan milik negara, yang berkembang mengerjakan pesanan kebutuhan militer pemerintah federal. Universitas kemudian menempatkan sumber daya ilmiah departemen berteknologi tinggi di wilayah research park tersebut. Dalam kurun waktu tiga puluh tahun, research park ini dapat mengembangkan industri berbasis ilmu pengetahuan. Research park ini adalah tempat asal dari Hewlett Packard dan Polaroid, yang menjadi perusahaan terkenal di dunia saat ini. Research park ini pula yang menghasilkan Silicon Valley.

Kontribusi technopark terhadap ekonomi Amerika Serikat diperhatikan dan didukung oleh pemerintah. Pada 1980-an, technoparks mulai muncul satu per satu di Amerika Serikat, dan pada akhir abad ke-20 jumlahnya mencapai lebih dari 160 buah (sekitar 30 persen dari total jumlah technoparks di seluruh dunia). Fungsi technopark sebagai "inkubator bisnis teknologi" mulai didirikan di dalam technoparks dengan jumlah yang semakin meningkat. Inkubator ini menawarkan tempat produksi dan beberapa layanan yang menjanjikan bagi pengusaha, serta membantu menjalin kontak dengan universitas lokal atau pusat penelitian, demikian juga dengan bantuan keuangan.

Di Eropa, technoparks mulai muncul pada awal tahun 1960 dengan berdirinya Sophia Antipolis (Perancis). Menggunakan model awal technopark Amerika yang memiliki pendiri tunggal dan terfokus pada menyewakan tanah dan ruangan untuk perusahaan berbasis ilmu pengetahuan. Sedangkan di Asia technopark diawali dengan berdirinya Tsukuba Science City di Jepang di tahun 1970, dimana sekarang Jepang memiliki 111 Technopark. Disusul oleh Cina yang mulai di tahun 1980 dan sekarang sudah memiliki 100 technopark.

Pada tahun 1990, Komite Pendidikan Masyarakat Negara Uni Soviet meluncurkan program untuk menciptakan dan mengembangkan technopark. Program ini dikelola oleh Kementrian Pendidikan. Awal 1990-an terlihat gelombang awal pendirian bangunan technoparks di Rusia. Sebagian besar didirikan di perguruan tinggi. Technopark ini tidak memiliki infrastruktur yang sudah berkembang, properti tetap, atau tim manajer yang terampil.

Sejarah technopark di India diawali dengan pendirian IT technopark di Trivandrum, Kerala, pada tahun 1995. Technopark ini telah berkembang menjadi IT Park yang terbesar di India dan ketiga terbesar di Asia dan merupakan rumah bagi raksasa perusahaan multinasional seperti Infosys, TCS, Ernst \& Young, IBS Software Services, UST Global, HCL Infosystems dll; mempekerjakan sekitar 30.000 orang di hampir 170 perusahaan.

Dalam aspek fungsi science park, Oh dan Kang (2009) membagi struktur utama science park berdasarkan fungsi dan komponennya. Fungsi utama science park adalah R\&D, bisnis dan networked entrepreneurship, manajemen dan globalisasi, dan infrastruktur. Tabel 1 berikut ini menjelaskan komponen-komponen dari tiap fungsi utamanya. 
JURNAL

MANAJEMEN

INDONESIA

Vol.18 No.1

April 2018

Tabel 1.

Fungsi Utama dan

Komponen Science Park

Sumber: Oh dan Kang, 2009

\begin{tabular}{|c|c|}
\hline Fungsi Utama & Komponen \\
\hline $\begin{array}{c}\text { Riset dan Pengembangan } \\
\text { (R\&D) }\end{array}$ & $\begin{array}{c}\text { Institusi Pendidikan Tinggi, R\&D publik, kolaborasi } \\
\text { R\&D, Komersialisasi Teknologi }\end{array}$ \\
\hline $\begin{array}{c}\text { Busnis \& jejaring } \\
\text { kewirausahaan }\end{array}$ & Kewirausahaan, inkubasi, modal ventura, jaringan \\
\hline Manajemen dan globalisasi & $\begin{array}{c}\text { Program training, bantuan keuangan, pemasaran, } \\
\text { properti untuk disewakan, globalisasi }\end{array}$ \\
\hline Infrastruktur & $\begin{array}{c}\text { Penggunaan lahan, fasilitas R\&D, fasilitas bisnis, } \\
\text { fasilitas manajemen, perumahan dan pemukiman }\end{array}$ \\
\hline
\end{tabular}

Di Indonesia, merujuk pada Kementerian Riset, Teknologi, dan Pendidikan Tinggi Republik Indonesia, sciencepark atau technopark didefinisikan sebagai suatu kawasan terpadu yang menggabungkan dunia industri, perguruan tinggi, pusat riset dan pelatihan, kewirausahaan, perbankan, pemerintah pusat dan daerah dalam satu lokasi yang memungkinkan aliran informasi dan teknologi secara lebih efisien dan cepat. Bertujuan sebagai wahana hilirisasi IPTEK untuk mendorong pertumbuhan ekonomi daerah melalui penyebaran pusat-pusat pertumbuhan dalam rangka pemerataan antar wilayah. Pengembangan science dan technopark dapat mendukung Pemerintah Indonesia dalam menghadapai tantangan revolusi Industri 4.0, dimana science dan technopark dapat menjadi ekosistem ataupun infrastruktur untuk riset dan pengembangan IPTEK yang tepat guna karena didukung dengan peran serta seluruh pemangku kepentingan yang terkait yaitu industri, pemerintah, akademisi, dan juga komunitas.

Berdasarkan Rencana Pengembangan Jangka Menengah Nasional (2015-2019), arah kebijakan nasional untuk Science Techno Park di Indonesia dibagi menjadi 3 (tiga) kategori, yaitu (Kementerian Perencanaan Pembangunan Nasional/ Bappenas, 2015):

1. National Science Tecno Park (Tingkat Nasional)

Didirikan pada tingkat nasional dan berfungsi sebagai pusat pengembangan sains dan teknologi, dengan fokus pada beberapa topik IPTEK prioritas yang ditentukan. National Science Tecno Park juga berfungsi sebagai inkubator untuk meningkatkan pertumbuhan kewirausahaan melalui proses spin off.

2. Science Park (Tingkat Provinsi)

Didirikan di tingkat provinsi sebagai penyedia teknologi yang tepat guna bagi masyarakat, juga dapat dipergunakan sebagai tempat untuk pembinaan dan pengembangan usaha melalui solusi teknologi, dan sebagai pusat pengembangan aplikasi teknologi untuk meningkatkan perekonomian lokal.

3. Techno Park (Tingkat Kabupatan/ Kota Madya)

Didirikan di tingkat kota atau kabupaten, sebagai pusat untuk penerapan teknologi yang dapat mendorong perekonomian pemerintah lokal dan dapat dipergunakan inkubator atau sebagai tempat pelatihan, magang dan konsultasi bisnis kepada masyarakat luas.

Kementrian Perencanaan Pembangunan Nasional/Bappenas (2015) telah membuat model technopark, layanan-layanan yang dapat diberikan, dan para aktor yang terlibat yaitu akademisi, pelaku bisnis (business), government (pemerintah), dan community (komunitas). Studi terhadap National Science Tecno Park diatas didasarkan pada framework yang merupakan sintesa dari beberapa teori yang terkait dengan Innovation System, Cluster dan Triple Helix concept.

Menurut Dirjen Kelembagaan Iptek dan Dikti, Dr. Ir. Patdono Suwignjo, M.Eng.Sc Science Techno Park memberikan pelayanan kepada para penggunanya dengan konsep 7-S, yaitu:

Jurnal Manajemen Indonesia 
1. Space and Share

Yaitu menyediakan fasilitas kantor seperti halnya ruang diskusi, laboratorium, internet, showroom maupun fastel dimana akan membantu dalam menjalankan program ataupun tujuan dari dibangunnya STP di suatu daerah.

2. Layanan (Service)

Yaitu dengan memberikan bimbingan teknis yang mencakup dalam manajemen, marketing, aspek keuangan, hukum, informasi perdagangan dan teknologi yang akan memudahkan pengguna dalam menjalankan strukturnya.

3. Dukungan (Support)

Yaitu membantu akses dalam riset atau penelitian seperti halnya alat dan bahan yang diperlukan serta tenaga kerja dalam penelitian, membantu akses jaringan profesional, pengembangan teknologi, hubungan internasional, serta investasi.

4. Pengembangan keahlian (Skill development)

Memberikan latihan dalam hal rencana bisnis, manajemen, maupun kepemimpinan, skill development seperti halnya di Solo Technopark melakukan program pendidikan dan pelatihan Basic Aircraft Structure Training atau Dasar Pesawat Pelatihan Struktur, dimana pendidikan dan pelatihan ini bertujuan untuk menciptakan tenaga kerja yang kompeten dan terampil dalam teknisi dan perawatan pesawat terbang.

5. Ketersediaan modal (Seed capital)

Memberikan bantuan akses ke sumber pendanaan dan lembaga keuangan atau dapat disebut sebagai sponsor yang mendanai kegiatan seperti penelitian, riset, ataupun kegiatan seperti festival maupun seminar dan pelatihan.

6. Sinergi (Synergy)

Kerjasama antar universitas, lembaga riset, usaha swasta, profesional dan masyarakat. Synergy sangat diperlukan dalam Science Techno Park sebagai pendukung dalam kegiatan ataupun program kerja dari STP itu sendiri. Seperti hal nya lembaga riset yang membantu dalam pemecahan masalah yang terjadi di daerah tersebut, dan universitas membantu mahasiswa dalam melakukan penelitian.

7. Jejaring social (Social networking)

Membangun jejaring melalui seminar, kunjungan dan pameran. Kegiatan social networking merupakan suatu hal yang bertujuan menyebar luaskan Science Techno Park ke seluruh kalangan baik mahasiswa, masyarakata ataupun pelajar, melalui kegiatan seminar, kunjungan ataupun pameran.

Pengembangan Science dan Technopark dalam menghadapi era Industri 4.0 harus mampu untuk mendukung peran Science dan Technopark sebagai Hub untuk mengakomodir proses komersialisasi teknologi dan besifat tematik, pemilihan teknologi yang diperlukan industri untuk setiap kawasan. Faktor yang sangat penting dalam mengembangkan Science dan Technopark dalam menghadapi era Industri 4.0 adalah:

- Kepemimpinan, yaitu pemimpin Science dan Technopark harus memiliki visi dan pandangan ke depan serta pola pikir entrepreneurial yang dapat membawa Science dan Technopark mencapai tujuan yang dicita-citakan dalam RPJMN

- Tata kelola atau mekanisme kerjasama antar aktor (internal dan eksternal), yaitu dengan membangun dukungan kuat pemerintah dan universitas/lemlitbang (sebagai owner sekaligus inisiator); dukungan industri sebagai basis investasi, pasar dan pelaku usaha; terbentuknya organisasi yang fleksibel, sehingga mampu membuat pengelola Science dan Technopark yang mandiri; tersedianya lahan dan infrastruktur dasar; tersusunnya manajemen profesional yang mampu menjalankan program sehingga mampu meningkatkan aspek relevansi, berkelanjutan dan kemandirian; serta terbangunnya komitmen jangka panjang daerah bagi tersedianya biaya operasional yang kontinyu.

- Untuk pengelolaaan Science dan Technopark dapat memilih beberapa alternatif sebagai berikut Direktorat - PT Holding, UPT, dan BLU. Bentuk pengembangan kelembagaan 
tersebut dapat dilakukan secara bertahap, sesuai dengan peraturan perundangan yang berlaku. Pilihan bentuk kelembagaan Science dan Technopark BLU ataupun BUMD, terkait dengan sifat pengelolaan Science dan Technopark yang profesional, efisien, efektif dan cenderung non birokratis.

JURNAL

MANAJEMEN

INDONESIA

- Pengembangan Science dan Technopark harus menitikberatkan pada kerjasama antar aktor yang terlibat, yaitu para aktor atau pelaku yang terlibat adalah akademisi atau lembaga penelitian, pemerintah, bisnis atau industri, dan komunitas, dimana seluruh aktor tersebut harus dilibatkan, sehingga tujuan pembentukan Science dan Technopark yaitu harus memberikan dampak pada masyarakat dalam meningkatkan atau menumbuhkan perekonomian suatu daerah dapat tercapai.

\section{Kesimpulan dan Riset Lanjutan}

Saat ini dunia sedang menghadapi tantangan revolusi Industri 4.0, dimana semua sistem mulai terhubung secara digital. Begitu pula Indonesia menghadapi tantangan terbesar menghadapi revolusi Industri 4.0 yaitu dalam menciptakan teknologi dan pendekatan baru yang menggabungkan dunia fisik dan digital. Salah satu strateginya adalah dengan pengembangan Science dan Technopark, yaitu sebagai hub yang dapat meningkatkan jejaring dan kolaborasi antar pemangku kepentingan. Tinjauan strategi ini dilakukan melalui benchmark terhadap beberapa negara yang telah membuat Science dan Technopark. Mengambil pembelajaran dari faktor-faktor kebarhasilan yang mereka miliki dan bagaimana Science dan Technopark dapat memberikan kontribusi terhadap perekonomian suatu negara.

Bappenas yaitu Badan Perencanaan Pembangunan Nasional, telah memasukkan pengembangan Science dan Technopark ke dalam Rencana Pembangunan Jangka Menengah Nasional (RPJMN) 2015-2019, bertujuan agar program ini berkelanjutan dan masuk ke dalam prioritas pemerintah. Sehingga dalam pelaksanaannya Bappenas kemudian menjabarkan pengembangan pengembangan Science dan Technopark dalam suatu pedoman panduan yang berisi Sasaran, Arah Kebijakan, dan Strategi Pembangunan Science dan Technopark; Model pengembangan Science dan Technopark; Pembangunan Science dan Technopark, berupa kewenangan dan proses perencanaan; serta dilengkapi dengan studi kasus mengenai perkembangan dan cakupan Science dan Technopark di Indonesia.

Riset lanjutan perlu dilakukan dengan menitikberatkan pada peran serta dari setiap pemangku kepentingan serta metoda dalam pemilihan prioritas IPTEK di setiap Science dan Technopark. Hal tersebut penting dilakukan karena mengetahui peran serta dari pemangku kepentingan akan membuat model Science dan Technopark yang dikembangkan berkelanjutan dan sesuai dalam menghadapi tantangan revolusi Industri 4.0, yang memiliki karakteristik yang berbeda dengan kondisi sebelumnya. Peran setiap pemangku kepentingan akan mengambil peranan yang sangat besar dalam keberhasilan Science dan Technopark dari sisi kepemimpinan dan manajemen Science dan Technopark. Metoda pemilihan prioritas IPTEK juga penting karena setiap daerah memiliki karakteristik dan sumber daya yang berbeda-beda, fokus riset lanjutan ini untuk menjembatani antara kebutuhan IPTEK yang harus dikembangkan yang diturunkan dari visi dan misi pemerintah dan juga kemampuan IPTEK dan sumber daya yang dimiliki daerah dimana Science dan Technopark akan dikembangkan.

\section{Daftar Pustaka}

Ashton, K. (2009). That 'internet of things' thing. RFID journal, 22(7), 97-114.

Atzori, L., Iera, A., \& Morabito, G. (2010). The internet of things: A survey. Computer networks, 54(15), 2787-2805.

Felsenstein, D. (1994). University-related science parks-'seedbeds' or 'enclaves' of innovation?. Technovation, 14(2), 93-110.

Jurnal Manajemen Indonesia 
Bappenas. (2015), Pedoman Perencanaan Science Park dan Techno Park Tahun 2015-2019, Unpublished paper.

GE Report, 2016, Apa itu Industri 4.0?, 2016, Retrieved at http://gereports.co.id/post/139409744260/apa-itu-industri-40

Hart, C. (1998). Doing a literature review: Releasing the social science research imagination. Sage.

IDCH, 2016, Mari Mengenal Apa itu Internet of Thing (IoT), retrieved at https://idcloudhost.com/mari-mengenal-apa-itu-internet-thing-iot/

Iivari, J., Hirschheim, R., \& Klein, H.K. (2004). Towards a distinctive body of knowledge for information systems experts: Coding ISD process knowledge in two IS journals. Information Systems Journal, 14(4), 313-342.

Kemper, J. (2016). The History of Industry 4.0, retrieved at https://www.linkedin.com/pulse/history-industry-40-james-kemper

Levy, Y., \& Ellis, T.J. (2006). A systems approach to conduct an effective literature review in support of information systems research. Informing Science: International Journal of an Emerging Transdiscipline, 9(1), 181-212.

Oh, D \& Kang, B. (2009). Creative Model of Science Park Development, Case study on Daedeok Innopolis, Unpublished paper.

Sniderman, B., Mahto, M., \& Cotteleer, M. J. (2016). Industry 4.0 and manufacturing ecosystems: Exploring the world of connected enterprises. Deloitte Consulting.

Tjandrawinata, R. R. (2016). Industri 4.0: revolusi industri abad ini dan pengaruhnya pada bidang kesehatan dan bioteknologi. Jakarta: Working Paper from Dexa Medica Group. 